\title{
Inheritance of Seed Set, Germination, and Day Neutrality/Heat Delay Insensitivity of Garden Chrysanthemums (Dendranthema xgrandiflora) under Glasshouse and Field Conditions
}

\author{
Neil O. Anderson ${ }^{1}$ and Peter D. Ascher ${ }^{2}$ \\ Department of Horticultural Science, University of Minnesota, 1970 Folwell Avenue, St. Paul, MN 55108 \\ AdDITIONAL INDEX wORDS. combining ability, cotyledon pigmentation, diallel, flower bud initiation, flower bud develop- \\ ment, self incompatibility, yield potential

\begin{abstract}
Commercial chrysanthemums are short day (SD) plants. Recently, several day neutral (DN) garden genotypes have been identified. Both glasshouse and garden cultivars vary in heat delay insensitivity (HDI). This research analyzed yield components (seed set, germination, yield potential) and tested a DN/HDI ideotype for its effectiveness. Progeny from a $6 \times 6$ diallel were embryo rescued, clonal ramats were grown in two environments (glasshouse-long days; field-long to short days) and evaluated for flowering, early flowering response groups, thermozero temperature response, low long day leaf number (LDLN), high leaf initiation rates, and low mean stem lengths of the terminal shoot. Self seedset ranged from $0 \%$ to $8 \%$ while outcross seedset was $0 \%$ to $92 \%$. General and specific combining ability were highly significant for seed set, the reciprocals, and their interactions. Germination averaged $67 \%$, while yield potential was $44 \%$. Cotyledon pigmentation in embryo rescued seedlings was $7 \%$ albinos, $15 \%$ anthocyanin (transposable elements), and $\mathbf{7 8 \%}$ normal (green). SD parents did not flower in either photoperiod although PPSL-10 carried alleles for DN. SD x DN crosses produced some DN progeny and fit a 1:3 chi square ratio(DN:SD), indicating DN to be recessive. However, DN x DN crosses also fit a 3:1 chi square ratio, due to HDI. No progeny flowered within the 3 to 6 week ideotype; visible bud date had a heritability of $h^{2}=0.50$. Most progeny were within the LDLN range $\left(h^{2}=0.72\right)$. Several leaf initiation rates exceeded the ideotype $\left(h^{2}=0.003\right)$; plant height also matched the ideotype $\left(h^{2}=0.66\right)$. Both visible bud and flowering dates require significant improvement before progeny match the DN/HDI ideotype.
\end{abstract}

Garden and glasshouse chrysanthemums, Dendranthema xgrandiflora Tzvelv., are allopolyploid $(2 n=6 x=54)$, self-incompatible (SI) outcrossers (Anderson et al., 1992). Cultivated chrysanthemums are vegetatively propagated, due to high levels of heterozygosity (Mulford, 1937). Inbred garden types have been created via pseudo-self compatibility (PSC), allowing for hybrid seed-propagated cultivars (Anderson and Ascher, 1996). Random outcrosses between noninbred, unrelated chrysanthemum parents produce $36 \%$ to $71 \%$ seed set, although $<50 \%$ is the norm (Ronald, 1974). Percent germination and yield potential declined in inbreds (Anderson et al., 1992).

Most glasshouse chrysanthemums are facultative short day (SD) plants for flower bud initiation (FBI), but qualitative (obligate) SD plants for flower bud development (FBD) (Cockshull and Kofranek, 1992). Garden and glasshouse chrysanthemums initiate terminal flower buds under long days (LD) (Langton, 1977) with characteristic subtending bracts. DN garden genotypes have been created that flower under any photoperiod (Anderson et al., 1989).

HDI can occur with both glasshouse and garden chrysanthemums under SD photoperiods induced with use of blackout material (black cloth) or in the field during summer months when the night temperatures are $\geq 22^{\circ} \mathrm{C}$ (de Jong, 1978). This can delay or prevent flowering. Typically, heat delay sensitivity is correlated with the same delay in flowering at temperatures below optimal for the species $\left(\leq 10^{\circ} \mathrm{C}\right)$ (de Jong, 1978). Thus, HDI garden chrysanthemums can also be grown during cool growing seasons.

Anderson and Ascher (2001) found three garden genotypes that

Received for publication 25 Aug. 2003. Accepted for publication 26 Jan 2004. Scientific journal series paper 011210099, Dept. of Horticultural Science.

${ }^{1}$ Assistant professor and corresponding author; e-mail ander044@umn.edu.

${ }^{2}$ Professor emeritus. were DN under various photoperiods. One genotype (83-267-3) was both DN and HDI for all flower buds. Other chrysanthemum genotypes differed for FBI and flowering requirements for the first six flower buds. An ideotype was proposed for DN and HDI garden chrysanthemums for use as a selection tool in the prescribed $\mathrm{LD}$, high temperature environment. The ideotype includes joint selection for the following traits: FBI and FBD in SD and LD, flowering response group, thermozero temperature response, low LDLN and high leaf initiation rate, and stem length of terminal shoot. For FBI/FBD in SD and LD photoperiods, the DN/HDI ideotype would flower (3 to 6 week response group) in SD (8 h light, $\geq 16.7^{\circ} \mathrm{C}$ night), LD far-red light (incandescent light, 2200 to $0200 \mathrm{HR}$ night interruption lighting, $\geq 26.7^{\circ} \mathrm{C}$ night), and continuous $(24 \mathrm{~h}) \mathrm{LD}$ far-red \pm red light $\left(\geq 28.3^{\circ} \mathrm{C}\right.$ day/night $)$ photoperiods. The terminal and subtending lateral flower buds would flower in all photoperiods. Selection would be for genotypes with low LDLN and early flowering. This would provide earlier flowering selections, provided the genotypes have sufficient vegetative growth to achieve commercially acceptable plant height. Genotypes would also be selected for a flat temperature response above or below $15.5^{\circ} \mathrm{C}$ (thermozero). Selections would possess LDLN in the range of 13 to 20 and a high leaf initiation rate of 0.58 to 0.82 leaves/d. LDLN has a broad sense heritability of $h^{2}$ $=0.79$ while leaf initiation rate heritability is $h^{2}=0.767$ (Langton and Cockshull, 1976). The DN/HDI ideotype also has low mean stem length heritability $\left(h^{2}=0.91\right)$.

This DN/HDI ideotype has yet to be tested for its effectiveness in producing the desired garden chrysanthemum phenotype. The objectives of this research were to use a diallel mating system to study yield components (seed set, germination, yield potential) and test the effectiveness of the DN/HDI ideotype in selecting genotypes with all traits. 


\section{Materials and Methods}

Parentaland hybridgermplasm. Six fertile inbred and recombinant inbred garden chrysanthemum parents determined DN/HDI inheritance: AGSL-1,PPSL-10, 83-267-3, 83-14-13, 81-45-15, and 85-341-9. The parental coefficients of inbreeding $(\mathrm{F})$ varied from $\mathrm{F}=0.0$ (AGSL-1, PPSL-1; Anderson, et al., 1992), $\mathrm{F}=0.3125$ (83-14-13), $\mathrm{F}=0.656$ (85-341-9; Anderson, et al., 1992), to $\mathrm{F}=$ 0.75 (81-45-15, 83-267-3). Previous research demonstrated the fertility levels, photoperiodic responses, and flowering under high temperatures for these six clones (Anderson and Ascher, 2001). Two parents were facultative SD for FBI and obligate SD for FBD (AGSL-1, PPSL-10), while the remainder were DN for FBI and FBD for some or all of the $1^{\text {st }} 6^{\text {th }}$ flower buds (Anderson and Ascher 2001). Only 83-267-3 was DN and HDI for the first to sixth flower buds; the remaining parental genotypes were sensitive to heat delay. The four DN parents represented two inbred families: 79-214-2 (83-267-3) and 77-AM2 (81-45-15, 83-14-13, 85-341-9).

All parents had low levels of PSC (Anderson and Ascher, 1996). Parents were crossed in a complete diallel (Method 1, Model 1, fixed effects; Griffing, 1956). To ensure minimal replication and environmental variation on fecundity, two crossing environments were used [cycle 1 (fall) and 2 (winter) glasshouse conditions, lat. $\left.45^{\circ} \mathrm{N}\right]$. Within each crossing cycle, pollinations were replicated three times (each inflorescence as a replication). Seed and ovule counts were made for all pollinations and were pooled for the crossing environments. Rapid generation cycling techniques of laboratory seed ripening and embryo rescue were used as crossing procedures to maximize seed set and decrease generation time (Anderson et al. 1990). Percent germination [ $\left(\sum\right.$ no. seeds germinating $/ \Sigma$ no. seeds sown $) \times 100]$ and yield potential $[(\Sigma$ transplanted seedlings $/ \sum$ no. seeds sown $) \times 100$ ] (PanAmerican Seed Co., 2001) were calculated.

Test ENVIRONMENTS. Before testing for DN/HDI, parents, the next inbred (selfing each parent) generation, and their $F_{1} s$ were grown in vitro for an average of $90 \mathrm{~d}$ after embryo rescue (progeny) or meristem culturing (parents). In vitro conditions were $25.6 \pm 1$ ${ }^{\circ} \mathrm{C}$ and $14 \mathrm{~h}$ photoperiod (red light, 630 to $690 \mathrm{~nm}, 0800$ to 2200 HR). Since plants do not photosynthesize when grown in vitro with $1 \%$ sucrose and no supplemental $\mathrm{CO}_{2}$, this culture environment reduced any potential impact of photosynthesis on FBI and FBD (Trevor-Chandler et al., 1972). At the termination of the culture period, each genotype produced lateral shoots that were used for in vivo test environments.

Genotypes were then established as stock plants in the glasshouse, maintained in a vegetative state with $\mathrm{LD}(>12 \mathrm{~h}$ d plus lighting, 2200 to $2000 \mathrm{HR}$ with fluorescent lamps) and weekly sprays of 11,984 $\mathrm{mg} \cdot \mathrm{L}^{-1}$ ethephon (Florel) plus $120 \mathrm{mg} \cdot \mathrm{L}^{-1} \mathrm{GA}_{3}$. Uniform cuttings from the basipetal lateral shoots $(\mathrm{n}=2$ replications/genotype/test environment) were taken, with equal leaf numbers and stem lengths of all cuttings (Anderson and Ascher, 2001). Cuttings were rooted in a mist bench (sand) for two weeks under a $14 \mathrm{~h}$ photoperiod, red light ( $>12$ h daylight plus lighting, 2200 to 0200 HR). Rooted cuttings were transferred to the test environments and grown in a completely randomized design. The glasshouse environment commenced on 14 Apr. 1988, and continued for 18.5 weeks. The field environment began on 6 June 1988, continuing for 17.2 weeks until a freeze.

Genotypes (glasshouse) were grown in 13.75-cm pots of high porosity soil (SunGro Horticulture, Bellevue, Wash.); field plants were rooted in 5-cm peat pots before planting. The glasshouses had a LD photoperiod ( $>12 \mathrm{~h}$ daylight plus lighting, 2200 to $0200 \mathrm{HR}$ ) and high temperatures $\left(30 \pm 2 / 25 \pm 1{ }^{\circ} \mathrm{C}\right.$, day/night). The field had a progression of LD to SD from 1 June $(15.2 \mathrm{~h})$ to 1 Oct. (11.7 h) (U.S. Nautical Almanac Office, 1977) and day/night temperatures of $28 \pm 12 / 15 \pm 10^{\circ} \mathrm{C}$ ( 1 June to 1 Oct.).

It was neither possible nor necessary to generate an $\mathrm{F}_{2}$ from the hybrid progeny, since the $\mathrm{F}_{1}$ generation were SI (data not shown) and populations segregated (Anderson and Ascher, 1996; Anderson, unpublished data). At germination, data were recorded on cotyledon pigmentation (albino-lacking chlorophyll, green-chlorophyll, anthocyanin transposable elements - red cells on a green or albino background). For genotypes grown in the glasshouse, data were collected on the no. of days to visible bud date, flowering of the terminal (first) and third flower buds, plant height (cm), LDLN, no. of bracts (strap-shaped leaves), and leaf initiation rate [(number of days to visible bud date)/LDLN]. In the field, flowering of the first and third flower buds was recorded. The fraction of flowering: nonflowering progeny (for the first flower) was calculated. The first flower is the critical bud to determine DN/HDI (Anderson and Ascher, 2001).

Data Analyses. Ovule counts and seed set data were analyzed using Self Incompatibility Genetic Modeling Application Systems, SIGMAS (Liedl and Anderson, 1986). Percent self seed set, percent outcross seed set, and percent PSC for the population and on a per plant basis were determined. Griffing's Method 1, Model 1 (fixed effects) diallel analysis was used for percent seedset to determine general (GCA) and specific combining ability (SCA) (Griffing, 1956). Diallel analysis was not performed for germination and yield potential due to missing data (nongerminating progeny, pooled replicates). Diallel analysis was done using DIALLELSAS (Zhang and Kang, 1997). Seed set data were transformed using empirical logits (due to the presence of zeroes caused by SI): $\ln ((a \pm 1 / 2) /(b \pm 1 / 2))$ where $a=$ no. of seeds and $b=($ no. of ovules - no. of seeds) or the no. of failed pollinations. The $1 / 2$ is included to eliminate zeroes.

For the glasshouse environment, reciprocal crosses were not bulked for visible bud date, height, LDLN, no. of bracts, and leaf initiation rate. Families with only one offspring were omitted from analysis. ANOVAs and multiple pairwise comparisons were performed. Height and no. of bracts required no data transformation; visible bud date and LDLN were both transformed by [sqrt(vbd) \pm sqrt(1 \pm vbd)] (Freeman and Tukey, 1950). The GT-2 (Hochberg, 1970) unplanned mean comparison was used for all four variables due to unequal sample sizes.

No transformation could stabilize the variance for leaf initiation rate; ANOVA was performed on the untransformed data. The $\mathrm{F}$ test is conservative because the family variances are correlated with family sample size. The Games-Howell minimum significant difference for comparison of means was used due to heterogeneity of the variance across families (Games and Howell, 1976). The minimum significant difference is given by

$\mathrm{MSD}_{\mathrm{ij}}=\mathrm{Q}_{\mathrm{a}\left[\mathrm{k}, v^{*}\right]}\left(\mathrm{S}_{\mathrm{Yi}_{\mathrm{i}}}{ }^{2} \pm \mathrm{s}_{\mathrm{Yj}}^{2}\right)^{1 / 2}$

where $\mathrm{V}^{*}=\left(\mathrm{s}_{\mathrm{Y}_{\mathrm{i}}} 2-\mathrm{s}_{\mathrm{Yi}} 2\right)$

$$
\frac{\left(\mathrm{s}_{\left.\mathrm{Y}_{\mathrm{i}}^{2}\right)^{2}} \pm \frac{\left(\mathrm{(}_{\left.\mathrm{Y}_{\mathrm{j}}\right)^{2}}\right.}{\left(\mathrm{n}_{\mathrm{i}}-1\right)}\right.}{\left(\mathrm{n}_{\mathrm{j}}-1\right)}
$$

and $\mathrm{k}=$ the number of treatments (families) and $\mathrm{Q}_{\alpha\left[\mathrm{k}, \mathrm{v}^{*}\right]}$ is obtained from a studentized range table.

Data analyses of flowering date of the terminal (first) flower from both environments included only plants that flowered. Field and glasshouse data were analyzed separately, since genotypes flowering in each environment differed. ANOVA and mean separations were not performed for flowering date, since family size 
and no. of flowering progeny varied widely. Instead, Chi-square $\left(\chi^{2}\right)$ tests for flowering:nonflowering segregations, as a measurement of DN/HDI, were performed for the simplest inheritance patterns of 1:1 (simplex $\mathrm{x}$ nulliplex), 3:1 (if DN and HDI were a) dominant in outcross progeny or $b$ ) not recessive and occurred in a heterozygous state for self progenies), and 1:3 (if DN and HDI were recessive in outcross progeny) (Langton, 1980). Reciprocals were bulked, but were still too small and values were pooled as SD selfed, SD x SD, SD x DN, DN x DN, DN selfed; heterogeneity $\chi^{2}$ tests were performed.

Hybrid means for visible bud date, height, LDLN, no. of bracts, and leaf initiation rates were regressed on midparent means (weighted least squared regression, due to unequal family sizes); families with $n=1$ progeny were eliminated. The regression coefficient was interpreted as narrow-sense heritability $\left(h^{2}\right)$. Family weights were computed using the Kempthorne-Tandon method (Kempthorne and Tandon, 1953). The reference was a segregating population (Fehr, 1987).

\section{Results}

Self seed set, pooled across crossing cycles 1 and 2, ranged from 0 to 64 seeds (data not shown). Percent self seed set ranged from $0 \%$ to $8.1 \%$ (Table 1 ). Outcross seed set ranged from 0 to 38 , while percent outcross seed set was $0 \%$ to $92.3 \%$ (Table 1). The mean outcross seed set (32.8) exceeded the mean self seed set (2.6), indicating an SI system (Liedl and Anderson, 1993). The percent PSC for the diallel was $7.9 \%$. On a per plant basis, percent PSC ranged from $0 \%(81-45-15 ; \mathrm{SI}), 0.7 \%$ (85-341-9), 6.0\% (PPSL-10), $7.1 \%$ (83-267-3), $10.4 \%$ (83-14-13), to $26.8 \%$ (AGSL-1).

Mean squares for seed set were highly significant for GCA(4.0, $P<0.001$, df = 5), SCA $(17.1, P<0.001$, df $=15)$, and reciprocals $(7.9, P<0.001, \mathrm{df}=15)$. All interactions with crossing cycles were also highly significant, i.e., GCA x environment $(7.5, P<0.001$, df $=5), \mathrm{SCA} \times$ environment $(8.7, P<0.001, \mathrm{df}=15)$, and reciprocals $\times$ environment $(5.4, P<0.001, \mathrm{df}=15)$.

Percent in vitro germination ranged from 0.0 to $100.0 \%$ with a mean of $67.3 \%$ (Table 2). In several instances both reciprocal hybrid crosses had 100\% germination, e.g., AGSL-1 x 85-341-9 (Table 2). In most other crosses, percent germination of reciprocals varied widely, e.g., AGSL-1 x 81-45-15. Similar to percent germination, in vivo yield potential ranged from $0.0 \%$ to $100.0 \%$ with a pooled mean of $44.1 \%$ (Table 2). Unlike the results found for germination, reciprocals differed for yield potential in all crosses. For selfs with $\mathrm{n}>1$ germinating progeny, the yield potential was as high as $45.0 \%$ (PPSL-10) to $60.0 \%$ (83-267-3) (Table 2).

Cotyledon pigmentation in embryo rescued progeny varied from green, to albino, and to anthocyanin transposable element expression (Fig. 1). Anthocyanins were expressed in several, but not all, individual cotyledon epidermis cells (Fig. 1). Anthocy- anin expression has never been observed with in vivo germinated chrysanthemums, but appears periodically with embryo rescued seedlings (N. Anderson, unpublished data). Mean cotyledon pigmentation of embryo rescued and germinated seedlings for all pollinations ranged from $6.9 \%$ (albino), $15.0 \%$ (anthocyanin), to $78.1 \%$ (chlorophyll) (Table 2). Albino seedlings continued to grow vegetatively in vitro and all true leaves were also albino (lethal). Anthocyanin pigmentation was not correlated with albinism (data not shown). Both 83-267-3 and PPSL-10 did not produce any albino seedling when used as parents (Table 2). AGSL-1 and the DN inbred parents from the 77-AM2 inbred family did produce albinos. All other parents yielded varying levels of albinos. Anthocyanin expression did not follow the same trends. Only selfs from two parents produced progeny with anthocyanin expression: 83-14-13 (66.6\%) and 83-267-3 (25.0\%) (Table 2). In all outcrosses except one there were reciprocal differences for anthocyanin expression, i.e., $0 \%$ in one direction and $>1 \%$ in the reciprocal. The exception was PPSL-10 x 85-341-9, i.e., 20.0\% anthocyanin expression and $70.0 \%$ for the reciprocal (Table 2 ).

The no. of days to visible bud ranged from 13.5 (85-341-9) to 63.5 (AGSL-1) for the parents (Table 3). Selfed progeny from 8314-13, 83-267-3, and 85-341-9 had higher mean number of days to flower than their parents. As expected, SD parents AGSL-1 and PPS1-10 did not flower under long days (Table 3). PPSL-10 carries DN alleles, however, as some selfed progeny flowered. Crosses between SD and DN parents produced some DN hybrid progeny (Table 3); in some instances the $\mathrm{F}_{1}$ hybrids flowered earlier than the DN parent. It was possible to select genotypes from the cross PPSL-10 x 83-14-13 that flowered < 25 d earlier than the parents. Conversely, some progeny from the cross AGSL-1 x 85-341-9 flowered $47 \mathrm{~d}$ later than either parent.

Analysis of the progeny flowering response showed the glasshouse to be more stringent (Table 4). SD $x$ DN fit a 1:3 ratio for the glasshouse $\left(\chi^{2}=0.5, P=0.83\right.$; Table 4$)$, indicating that $\mathrm{DN}$ is recessive to SD. Crossing DN $x$ DN parents fit a 3:1 ratio $\left(\chi^{2}=0.4, P=0.5\right.$; Table 4) although only 64/82 (78\%) flowered, rather than $100 \%$ as would be expected. However, HDI is a confounding factor.

Average plant height ranged from 18.0 to $45.1 \mathrm{~cm}$ (Table 5). Progeny from the cross 83-14-13 x AGSL-1 were significantly shorter than those from 85-341-9 x PPSL-10 (Table 5). The remainder overlapped in their distribution. Average progeny height for reciprocals were split between being a) similar to the midparent value, e.g., AGSL-1 x PPSL-10, etc. or b) greater than the high parent value, e.g., AGSL-1 x 83-14-13, etc. (Table 5).

LDLN ranged from an average of 12 to 32 (Table 5) and were not significantly different. The no. of bracts ranged from 2.0 to 10.7 (Table 5) and most were not significantly different. Leaf initiation rates varied from 0.43 to 1.74 for the progeny (Table 5). The cross 85-341-9 x PPSL-10 had the lowest leaf initiation rate and was significantly different from 83-267-3 x 85-341-9, 81-45-15

Table 1. SIGMAS computer printout of percent seed set for selfs and crosses in a $6 \times 6$ diallel between four day neutral (81-45-15, 83-14-13,83-2673, 85-341-9) and two short day (AGSL-1, PPSL-10) chrysanthemum parents. Data were pooled from cycles 1 and 2 crossing environments.

\begin{tabular}{|c|c|c|c|c|c|c|}
\hline \multirow[b]{2}{*}{ Female } & \multicolumn{6}{|c|}{ Male } \\
\hline & $\overline{\mathrm{AGSL}-1}$ & PPSL-10 & $81-45-15$ & $83-14-13$ & $83-267-3$ & $85-341-9$ \\
\hline$\overline{\text { AGSL-1 }}$ & 8.1 & 92.3 & 27.3 & 12.5 & 34.3 & 24.0 \\
\hline PPSL-10 & 27.3 & 3.0 & 27.3 & 71.4 & 48.5 & 67.6 \\
\hline $81-45-15$ & 48.6 & 67.3 & 0.0 & 63.6 & 55.1 & 60.9 \\
\hline $83-14-13$ & 19.6 & 4.0 & 3.3 & 2.0 & 11.1 & 6.8 \\
\hline $83-267-3$ & 4.3 & 67.3 & 1.7 & 4.0 & 2.3 & 43.1 \\
\hline $85-341-9$ & 11.0 & 28.6 & 2.2 & 0.0 & 47.5 & 0.2 \\
\hline
\end{tabular}


Table 2. Number of embryo rescued (ER) chrysanthemum progeny, percent in vitro germination, percent cotyledon pigmentation, and percent in vivo yield potential derived from selfing and crossing parents in a $6 \times 6$ diallel.

\begin{tabular}{|c|c|c|c|c|c|c|c|}
\hline \multicolumn{2}{|c|}{ Pollination } & \multirow{2}{*}{$\begin{array}{c}\text { ER } \\
\text { progeny } \\
\text { (no.) }\end{array}$} & \multirow{2}{*}{$\begin{array}{c}\text { In vitro } \\
\text { germination } \\
(\%)\end{array}$} & \multicolumn{3}{|c|}{$\begin{array}{l}\text { Cotyledon } \\
\text { pigmentation } \\
(\%)\end{array}$} & \multirow{2}{*}{$\begin{array}{c}\text { In vivo } \\
\text { yield } \\
\text { potential } \\
(\%)\end{array}$} \\
\hline Female parent & Male parent & & & $\mathrm{A}$ & $\mathrm{C}$ & $\mathrm{Al}$ & \\
\hline \multirow[t]{6}{*}{ AGSL-1 } & Selfed & 64 & 36.4 & 0.0 & 50.0 & 50.0 & 7.8 \\
\hline & x PPSL-10 & 12 & 83.3 & 0.0 & 100.0 & 0.0 & 83.3 \\
\hline & $x 81-45-15$ & 9 & 100.0 & 22.2 & 66.7 & 11.1 & 66.7 \\
\hline & x 83-14-13 & 3 & 100.0 & 0.0 & 66.7 & 33.3 & 100.0 \\
\hline & x 83-267-3 & 12 & 83.3 & 0.0 & 100.0 & 0.0 & 75.0 \\
\hline & x 85-341-9 & 12 & 100.0 & 8.3 & 8.3 & 83.4 & 91.7 \\
\hline \multirow[t]{6}{*}{ PPSL-10 } & Selfed & 20 & 62.5 & 0.0 & 100.0 & 0.0 & 45.0 \\
\hline & x AGSL-1 & 3 & 33.3 & 0.0 & 100.0 & 0.0 & 33.3 \\
\hline & x 81-45-15 & 6 & 100.0 & 0.0 & 100.0 & 0.0 & 66.7 \\
\hline & x 83-14-13 & 15 & 90.9 & 60.0 & 40.0 & 0.0 & 33.3 \\
\hline & x 83-267-3 & 16 & 62.5 & 0.0 & 100.0 & 0.0 & 62.5 \\
\hline & x 85-341-9 & 23 & 78.9 & 20.0 & 81.0 & 0.0 & 47.8 \\
\hline \multirow[t]{6}{*}{$81-45-15$} & Selfed & 0 & $---y$ & --- & --- & --- & --- \\
\hline & x AGSL-1 & 35 & 46.7 & 0.0 & 100.0 & 0.0 & 48.6 \\
\hline & x PPSL-10 & 33 & 100.0 & 15.0 & 85.0 & 0.0 & 84.8 \\
\hline & x 83-14-13 & 21 & 100.0 & 100.0 & 0.0 & 0.0 & 4.8 \\
\hline & x 83-267-3 & 38 & 72.2 & 0.0 & 100.0 & 0.0 & 68.4 \\
\hline & x 85-341-9 & 28 & 100.0 & 0.0 & 95.0 & 5.0 & 64.3 \\
\hline \multirow[t]{6}{*}{ 83-14-13 } & Selfed & 7 & 85.7 & 66.6 & 16.7 & 16.7 & 14.3 \\
\hline & x AGSL-1 & 10 & 50.0 & 100.0 & 0.0 & 0.0 & 20.0 \\
\hline & x PPSL-10 & 1 & 100.0 & 0.0 & 100.0 & 0.0 & 0.0 \\
\hline & x 81-45-15 & 1 & 100.0 & 0.0 & 100.0 & 0.0 & 100.0 \\
\hline & x 83-267-3 & 10 & 100.0 & 0.0 & 100.0 & 0.0 & 20.0 \\
\hline & x 85-341-9 & 6 & 0.0 & --- & --- & --- & --- \\
\hline \multirow[t]{6}{*}{$83-267-3$} & Selfed & 10 & 40.0 & 25.0 & 75.0 & 0.0 & 60.0 \\
\hline & x AGSL-1 & 2 & 50.0 & 0.0 & 100.0 & 0.0 & 0.0 \\
\hline & x PPSL-10 & 35 & 6.9 & 0.0 & 100.0 & 0.0 & 11.4 \\
\hline & x 81-45-15 & 1 & 0.0 & --- & --- & --- & --- \\
\hline & x 83-14-13 & 1 & 0.0 & --- & --- & --- & --- \\
\hline & x 85-341-9 & 25 & 42.8 & 0.0 & 100.0 & 0.0 & 36.0 \\
\hline \multirow[t]{6}{*}{$85-341-9$} & Selfed & 1 & 100.0 & 0.0 & 100.0 & 0.0 & 100.0 \\
\hline & x AGSL-1 & 10 & 100.0 & 0.0 & 100.0 & 0.0 & 100.0 \\
\hline & x PPSL-10 & 16 & 62.5 & 70.0 & 30.0 & 0.0 & 18.8 \\
\hline & x 81-45-15 & 2 & 0.0 & --- & --- & --- & --- \\
\hline & x 83-14-13 & 0 & --- & --- & --- & --- & --- \\
\hline & x 83-267-3 & 38 & 100.0 & 0.0 & 100.0 & 0.0 & 34.2 \\
\hline Pooled & & 526 & 67.3 & 15.0 & 78.1 & 6.9 & 44.1 \\
\hline
\end{tabular}

${ }^{\mathrm{z}} \mathrm{As}$ a percentage of germinated seedlings, rather than seed set. Cotyledon pigmentation abbreviations: $\mathrm{A}=$ anthocyanin expression in cotyledonary cells (transposable elements), $\mathrm{C}=$ chlorophyll (normal), $\mathrm{Al}=$ white, albino cotyledons (these did not always produce albino true leaves).

yNo data available due either to the lack of seed set or $0 \%$ germination.

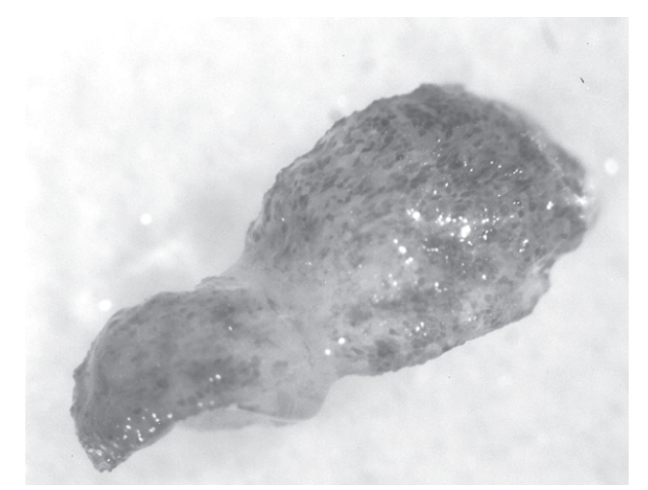

Fig. 1. Cotyledon pigmentation of embryo rescued chrysanthemum seedlings with anthocyanin transposable element expression (darker colored L1 cells) in an albino background. x 83-267-3, 81-45-15 x 85-341-9, PPSL-10 x 81-45-15, AGSL-1 $x$ 83-14-13, and AGSL-1 x 83-267-3 (Table 5). The remaining progeny overlapped between these groups.

Mean squares for visible bud date, height, LDLN, no. of bracts, and leaf initiation rates were highly significant $(P<0.001)$ for the families, intercept, and corrected model (data not shown). Mean square errors were significant at varying levels for visible bud date (MSE $=768, P<0.05)$, height $(\mathrm{MSE}=413, P<0.01)$, and LDLN (MSE $=456, P<0.001)$. The increase in significance also meant a corollary rise in heritability $\left(h^{2}\right)$ estimates: $h^{2}=0.50 \pm 0.14$ for visible bud date, $h^{2}=0.66 \pm 0.12$ for height, and $h^{2}=0.72 \pm 0.19$ for LDLN. The MSE were not significant for no. of bracts and leaf initiation rates; the $h^{2}$ were negligible $\left(h^{2}=0.1 \pm 0.17, h^{2}=0.003 \pm\right.$ 0.14 , respectively). 


\section{Discussion}

The continued expression of SI in advanced inbred and recombinant inbred parents underscores the role of this reproductive barrier in limiting inbred parent development for $F_{1}$ hybrid seed production. Percent PSC levels reported previously (Anderson and Ascher, 1996) for three parents were similar to levels in the present study. Mean outcross seed set $(32.8 \%)$ was lower than previous reports (36\% to $71 \%$ ) in random outcross pollinations (Ronald, 1974). Such low levels of outcross seed set are attributable to matched $S$ alleles between inbreds and/or inbreeding depression, rather than source-sink interactions (Anderson et al., 1990).

Both SCA and GCA were highly significant for seed set, indicating that both nonadditive and additive gene action are important in this species (Gravois and McNew, 1993). Highly

Table 3. Average +SD number of days to visible bud and flowering of the first (terminal) flower in chrysanthemum parents and $\mathrm{F}_{1}$ progeny from a

$6 \times 6$ diallel grown under the glasshouse screening environment (long days, high temperature). There were two replications per genotype.

\begin{tabular}{|c|c|c|c|c|c|}
\hline \multirow[b]{2}{*}{ Female parent } & \multirow[b]{2}{*}{ Male parent } & \multicolumn{2}{|c|}{$\begin{array}{l}\text { No. days to } \\
\text { visible bud }\end{array}$} & \multicolumn{2}{|c|}{$\begin{array}{l}\text { No. days to } \\
\text { first flower }\end{array}$} \\
\hline & & Avg & $\pm \mathrm{SD}$ & Avg & $\pm \mathrm{SD}$ \\
\hline \multirow[t]{7}{*}{$\overline{\mathrm{AGSL}}-1$} & Parent & 63.5 & $1.5^{z}$ & ---y & $---y$ \\
\hline & Selfed & 56.0 & $17.8 \mathrm{~cd}$ & --- & --- \\
\hline & x PPSL-10 & 36.0 & $24.2 \mathrm{bcd}$ & --- & --- \\
\hline & $x 81-45-15$ & 42.1 & $38.0 \mathrm{bcd}$ & --- & --- \\
\hline & x 83-14-13 & 29.0 & $7.3 \mathrm{abcd}$ & 58.5 & 10.2 \\
\hline & x 83-267-3 & 26.2 & $7.3 \mathrm{abcd}$ & --- & --- \\
\hline & x 85-341-9 & 23.8 & $16.0 \mathrm{abcd}$ & 73.5 & 20.8 \\
\hline \multirow[t]{7}{*}{ PPSL-10 } & Parent & 60.5 & 1.5 & --- & --- \\
\hline & Selfed & 19.9 & $18.5 \mathrm{ab}$ & 78.0 & 44.0 \\
\hline & x AGSL-1 & 62.0 & 0.0 & --- & --- \\
\hline & x 81-45-15 & 27.4 & $8.4 \mathrm{abcd}$ & 67.0 & 7.0 \\
\hline & x 83-14-13 & 20.6 & 9.4 & 60.0 & 27.6 \\
\hline & x 83-267-3 & 39.8 & $24.9 \mathrm{bcd}$ & 94.5 & 15.5 \\
\hline & x 85-341-9 & 20.3 & $8.9 \mathrm{ab}$ & 70.0 & 16.4 \\
\hline \multirow[t]{7}{*}{$81-45-15$} & Parent & 36.0 & 0.0 & 77.0 & 2.0 \\
\hline & Selfed & ---y & $---y$ & --- & --- \\
\hline & x AGSL-1 & 43.2 & $18.6 \mathrm{bcd}$ & 100.8 & 28.8 \\
\hline & x PPSL-10 & 30.7 & $20.2 \mathrm{abcd}$ & 78.5 & 31.6 \\
\hline & x 83-14-13 & 26.0 & 0.0 & 91.0 & 0.0 \\
\hline & x 83-267-3 & 26.1 & $12.9 \mathrm{abcd}$ & 70.2 & 21.0 \\
\hline & x 85-341-9 & 29.7 & $13.2 \mathrm{abcd}$ & 79.2 & 23.0 \\
\hline \multirow[t]{7}{*}{$83-14-13$} & Parent & 14.0 & 5.0 & 50.5 & 7.5 \\
\hline & Selfed & 22.0 & $0.0 \mathrm{ab}$ & 60.5 & 25.0 \\
\hline & x AGSL-1 & 10.5 & $11.8 \mathrm{a}$ & --- & --- \\
\hline & x PPSL-10 & --- & --- & --- & --- \\
\hline & x 81-45-15 & 55.5 & 0.5 & --- & --- \\
\hline & x 83-267-3 & 14.0 & 5.0 & 50.0 & 5.4 \\
\hline & x 85-341-9 & --- & --- & --- & --- \\
\hline \multirow[t]{7}{*}{$83-267-3$} & Parent & 16.5 & 2.5 & 50.0 & 2.0 \\
\hline & Selfed & 26.2 & $18.2 \mathrm{abc}$ & 55.6 & 23.7 \\
\hline & x AGSL-1 & --- & --- & --- & --- \\
\hline & x PPSL-10 & 38.8 & $22.1 \mathrm{bcd}$ & 96.5 & 5.5 \\
\hline & x 81-45-15 & --- & --- & --- & --- \\
\hline & x 83-14-13 & 16.0 & 10.0 & 104.0 & 25.0 \\
\hline & x 85-341-9 & 31.4 & $14.1 \mathrm{abcd}$ & 65.7 & 28.9 \\
\hline \multirow[t]{7}{*}{$85-341-9$} & Parent & 13.5 & 2.5 & 47.0 & 4.0 \\
\hline & Selfed & 43.0 & 17.0 & 104.0 & 22.0 \\
\hline & x AGSL-1 & --- & --- & --- & --- \\
\hline & x PPSL-10 & 58.5 & $4.8 \mathrm{~d}$ & 120.5 & 8.5 \\
\hline & x 81-45-15 & --- & --- & --- & --- \\
\hline & x 83-14-13 & --- & --- & --- & --- \\
\hline & x 83-267-3 & 27.4 & $22.6 a b c$ & 74.5 & 25.7 \\
\hline $\mathrm{MSE}^{\mathrm{x}}$ & & 12.8 & & 559.0 & \\
\hline
\end{tabular}

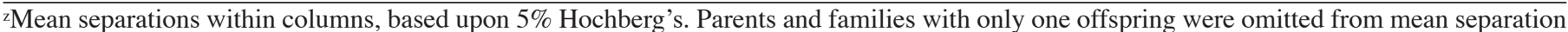
analysis.

yNo progeny were available for analysis (visible bud date) or no progeny flowered (first flower date).

xEstimation of mean square error (MSE) used to calculate $5 \%$ Hochberg's significant difference for mean separations. Means followed by different letters are significantly different from each other. 
Table 4. Flowering response of the terminal or first flower bud $(+/-z)$ and $\chi^{2}$ analysis (day neutral:short day, DN:SD) of chrysanthemum progeny from a $6 \times 6$ diallel with two SD and four DN parents. Pollinations were pooled by crossing type. Progeny and parents were grown under two photoperiod environments: glasshouse and field (see text for delineation of light and temperatures).

\begin{tabular}{|c|c|c|c|c|c|c|c|c|c|c|c|c|c|c|c|c|}
\hline \multirow{3}{*}{$\begin{array}{l}\text { Pooled } \\
\text { Pollinations } \\
\end{array}$} & \multicolumn{8}{|c|}{ Greenhouse environment } & \multicolumn{8}{|c|}{ Field environment } \\
\hline & \multicolumn{2}{|c|}{ Progeny (no.) } & \multicolumn{2}{|c|}{$1: 1$} & \multicolumn{2}{|c|}{$1: 3$} & \multicolumn{2}{|c|}{$3: 1$} & \multicolumn{2}{|c|}{ Progeny (no.) } & \multicolumn{2}{|c|}{$1: 1$} & \multicolumn{2}{|c|}{$1: 3$} & \multicolumn{2}{|c|}{$3: 1$} \\
\hline & + & - & $\chi^{2}$ & $P$ & $\chi^{2}$ & $\mathrm{P}$ & $\chi^{2}$ & $P$ & + & - & $\chi^{2}$ & $P$ & $\chi^{2}$ & $P$ & $\chi^{2}$ & $P$ \\
\hline SD selfed & 2 & 12 & $---y^{\prime}$ & --- & $---y^{\prime}$ & --- & $---y$ & --- & 1 & 13 & $---y$ & --- & $---y$ & --- & $---y$ & --- \\
\hline $\mathrm{SD} \times \mathrm{SD}$ & 0 & 11 & --- & --- & --- & --- & --- & --- & 0 & 11 & --- & --- & --- & --- & --- & --- \\
\hline $\mathrm{SD} \times \mathrm{DN}$ & 32 & 83 & 22.6 & $<0.01$ & 0.5 & 0.83 & 136.5 & $<0.01$ & 39 & 76 & 11.9 & $<0.01$ & 4.9 & 0.04 & 103.5 & $<0.01$ \\
\hline $\mathrm{DN} \times \mathrm{DN}$ & 64 & 18 & 25.8 & $<0.01$ & 123.1 & $<0.01$ & 0.4 & 0.5 & 79 & 3 & 70.4 & $<0.01$ & 222.6 & $<0.01$ & 19.9 & $<0.01$ \\
\hline DN selfed & 6 & 2 & --- & --- & --- & --- & --- & --- & 6 & 2 & --- & --- & --- & --- & --- & --- \\
\hline
\end{tabular}

${ }^{2}$ Flowering (+) denoted day neutral and non-flowering (-) signified short day responses.

yPooled progeny sizes were still too small to derive meaningful interpretations of inheritance.

significant SCA and GCA infer that hybrid production or pure lines could improve seedset.

Parents used in this study were at varying levels of inbreeding, ranging from $F=0.0$ to $F=0.75$. None were inbred far enough to be classified as homozygous $(\mathrm{F}=1.0)$ for the selected traits. This may be the most important factor contributing to the wide range of variability noted for the number of days to visible bud, first flower, plant height, LDLN, number of bracts, and the leaf initiation rate (Tables 3 and 5). For instance, crossing recombinant inbreds with a coefficient of inbreeding at $F=0.0$ (since inbreeding and crossing are juxtaposed, cf., Anderson et al., 1992) often produced higher variance levels for number of days to visible bud and first flower (Table 3). Likewise, parents with $\mathrm{F}=0.0$ when crossed with inbreds $(\mathrm{F}>0.0)$ reduced the variance for visible bud date, e.g., AGSL-1 x PPSL-10 (30.7 \pm 20.2 , Table $3)$ vs. AGSL-1 x 83-267-3 (26.1 \pm 12.9 , Table 3$)$. There were exceptions to this trend, i.e., contrast the variances of progeny for visible bud date from the crossing 85-341-9 x PPSL-10 and 85-341-9 x 83-267-3 (Table 3).

While germination had a pooled mean of $67.3 \%$ (Table 2), many individual crosses within the diallel had $0 \%$. Commercial germination standards are $>70 \%$ (PanAmerican Seed Co., 2001). Clearly many crosses were substandard (Table 2). In several crosses, extreme reciprocal differences existed (Table 2). In several instances, reciprocals had $100 \%$ germination, i.e., AGSL-1 x 85-341-9, PPSL-10 x 81-45-15, and 81-45-15 x 83-14-13 (Table 2 ). Thus, testing for SCA is important. Yield potential averaged $44.1 \%$ (Table 2); lower than industry standards (PanAmerican Seed Co., 2001). All crosses had reciprocal differences for yield potential. Yield potentials for the crosses with $100 \%$ germination in both directions varied from $4.8 \%$ to $100 \%(81-45-15 x$ $83-14-13$ and reciprocal) to $91.7 \%$ to $100 \%$ (AGSL-1 x 85-341$9 \&$ reciprocal) (Table 2 ). Only the reciprocal crosses between AGSL-1 and 85-341-9 met the minimum yield potentials in both directions, although $<100 \%$ of the progeny was DN/HDI. Thus, further inbreeding is necessary to obtain DN/HDI hybrids with acceptable germination and yield potentials.

Albinism in cotyledons and true leaves is a lethal condition, averaging $6.9 \%$ (Table 2 ). Only two parents produced selfed albino seedlings: AGSL-1 and 83-14-13 (Table 2). Inbreeding removed the recessive allele(s) for albinism in PPSL-10 and 83-267-3, as they produced $0 \%$ albino seedlings. Albino cotyledons and true leaves in seedlings have been reported in other ornamental taxa, e.g., Aquilegia (Hodgins, 1985). Cotyledon pigmentation may be a useful tool for early detection of flower pigmentation in germinated seedlings. Albino seedlings, without anthocyanin or carotenoid pigmentation, may result in flowers without either pig- ment system (white-flowered) (Anderson et al., 1988). Likewise, anthocyanin pigmentation in the cotyledons may be indicative of red (anthocyanins and carotenoids, with higher concentrations of the former), bronze/orange (anthocyanins and carotenoids in approximately equal quantities), or purple/lavender (anthocyanins only) flower coloration. The potential use of cotyledon pigmentation as an early screening for flower color in inheritance studies was not followed in the present study. Further research would be necessary to establish whether or not cotyledon and flower petal pigmentation are linked and if the same anthocyanin pigment(s) are produced in both tissues. If they are, flower color inheritance studies would be simplified with cotyledon expression of anthocyanin pigments.

Anthocyanin pigmentation occurred randomly in many, but never all, of the L1 layer epidermal cells of cotyledon tissue of embryo rescued seedlings (Table 2). This is the first report of anthocyanin expression in cotyledonary tissue of $D . \times$ grandiflora seedlings. Retroposon-like elements have been reported in $D$. pacificum (Shimizu, et al. 1998). Cotyledon-specific anthocyanin production did not occur in crosses between the inbred families 77-AM2 and 79-214-2 (Table 2), although selfed progeny from 83-267-3 (79-214-2 inbred family) expressed anthocyanins. Reciprocal differences did occur for anthocyanin expression (Table 2 ). Since anthocyanin expression is cotyledon-specific, this may be due to genomic shock (embryo rescue). Likewise, the random production of anthocyanin pigments by epidermal cells suggests this may be due to controlling and/or transposable elements.

Anderson and Ascher (2001) proposed an ideotype for DN/HDI garden chrysanthemums for use as a selection tool. Genotypes matching the DN/HDI ideotype would rapidly initiate and develop terminal flower buds in any photoperiod. Progeny from crossing 83-14-13 x AGSL-1 had the significantly lowest number of days to visible bud (initiation), but the $F_{1}$ failed to develop to anthesis (Table 3). Three selfed or $\mathrm{F}_{1}$ hybrid progeny (PPSL-10 selfed, PPSL-10 x 85-341-19, 83-14-13 selfed) overlapped with 83-14-13 $x$ AGSL-1 for no. of days to visible bud (Table 3 ). These three progeny all flowered, with 83-14-13 selfed progeny being earlier $(60.5 \mathrm{~d})$ than the other two (70 to $78 \mathrm{~d}$ ). No inbred or hybrid progeny flowered within the 3 to 6 week response group cutoff from the ideotype. Clearly further inbreeding and selection for earlier PPSL-10 and 83-14-13 inbreds is necessary. VBD was heritable $\left(h^{2}=0.5\right)$, although less than other traits (Langton and Cockshull, 1976). PPSL-10 appears to carry genes for DN since the inbreds flowered but the parent did not (Table 3). Also, unlike AGSL-1, SD x DN crosses with PPSL-10 consistently produced some DN progeny that often flower earlier than the DN parent (Table 3). 
Table 5. Average +SD plant height, long day leaf number (LDLN), number of bracts, and leaf initiation rates in chrysanthemum parents and progeny, derived from a $6 \times 6$ diallel grown under the glasshouse screening environment (long days, high temperature). There were two replications per genotype.

\begin{tabular}{|c|c|c|c|c|c|c|c|c|c|}
\hline \multirow[b]{2}{*}{ Female parent } & \multirow[b]{2}{*}{ Male parent avg } & \multicolumn{2}{|c|}{ Plant ht $(\mathrm{cm})$} & \multicolumn{2}{|c|}{ LDLN } & \multicolumn{2}{|c|}{$\begin{array}{c}\text { Bracts } \\
\text { (no.) }\end{array}$} & \multicolumn{2}{|c|}{$\begin{array}{c}\text { Leaf } \\
\text { initiation } \\
\text { rate }\end{array}$} \\
\hline & & Avg & $\pm \mathrm{SD}$ & Avg & $\pm \mathrm{SD}$ & $\overline{A v g}$ & $\pm \mathrm{SD}$ & $\overline{A v g}$ & $\pm \mathrm{SD}$ \\
\hline \multirow[t]{7}{*}{$\overline{\text { AGSL-1 }}$} & Parent & 13.2 & $0.8^{z}$ & 22.0 & $0.0^{z}$ & 0.0 & $0.0^{\mathrm{z}}$ & 0.4 & $0.01^{\mathrm{y}}$ \\
\hline & Selfed & 20.6 & $2.2 \mathrm{ab}$ & 25.0 & $3.0 \mathrm{a}$ & 3.5 & $3.3 \mathrm{a}$ & 0.8 & $1.02 \mathrm{ab}$ \\
\hline & x PPSL-10 & 20.0 & $8.2 \mathrm{ab}$ & 18.8 & $5.9 \mathrm{a}$ & 4.4 & $2.1 \mathrm{ab}$ & 0.55 & $0.17 \mathrm{ab}$ \\
\hline & x 81-45-15 & 20.2 & $10.9 \mathrm{ab}$ & 19.5 & $6.1 \mathrm{a}$ & 2.9 & $2.1 \mathrm{ab}$ & 0.66 & $0.27 \mathrm{ab}$ \\
\hline & x 83-14-13 & 25.8 & $11.4 \mathrm{abc}$ & 20.3 & $4.8 \mathrm{a}$ & 10.7 & $15.0 \mathrm{ab}$ & 0.71 & $0.08 \mathrm{~b}$ \\
\hline & x 83-267-3 & 28.9 & $12.9 \mathrm{ab}$ & 19.8 & $5.5 \mathrm{a}$ & 4.5 & $1.7 \mathrm{ab}$ & 0.77 & $0.14 \mathrm{~b}$ \\
\hline & x 85-341-9 & 24.4 & $6.8 \mathrm{ab}$ & 19.6 & $5.0 \mathrm{a}$ & 4.0 & $1.8 \mathrm{ab}$ & 0.72 & $0.23 \mathrm{ab}$ \\
\hline \multirow[t]{7}{*}{ PPSL-10 } & Parent & 30.2 & 3.2 & 21.0 & 0.0 & 3.5 & 0.5 & 0.34 & 0.01 \\
\hline & Selfed & 26.4 & $12.2 \mathrm{ab}$ & 16.1 & $5.7 \mathrm{a}$ & 3.9 & $1.5 \mathrm{ab}$ & 0.86 & $0.53 \mathrm{ab}$ \\
\hline & x aGSL-1 & 28.8 & 0.8 & 32.0 & 3.0 & 3.0 & 1.0 & 0.52 & 0.04 \\
\hline & x 81-45-15 & 32.7 & $4.8 \mathrm{abc}$ & 22.0 & $6.5 \mathrm{a}$ & 2.4 & $0.7 \mathrm{a}$ & 0.84 & $0.19 \mathrm{~b}$ \\
\hline & x 83-14-13 & 23.2 & $10.1 \mathrm{ab}$ & 15.1 & $4.8 \mathrm{a}$ & 3.6 & $2.4 \mathrm{ab}$ & 0.74 & $0.23 \mathrm{ab}$ \\
\hline & x 83-267-3 & 31.9 & $10.5 \mathrm{abc}$ & 20.4 & $5.6 \mathrm{a}$ & 4.2 & $2.3 \mathrm{ab}$ & 0.58 & $0.17 \mathrm{ab}$ \\
\hline & x 85-341-9 & 27.6 & $9.6 \mathrm{abc}$ & 15.8 & $3.8 \mathrm{a}$ & 3.4 & $1.9 \mathrm{ab}$ & 0.71 & $0.16 \mathrm{ab}$ \\
\hline \multirow[t]{7}{*}{$81-45-15$} & Paren & 45.8 & 0.8 & 22.0 & 0.0 & 2.0 & 0.0 & 0.61 & 0.00 \\
\hline & Selfed & $---x$ & --- & --- & --- & --- & --- & --- & --- \\
\hline & x aGSL-1 & 36.0 & $11.4 \mathrm{bc}$ & 24.5 & $8.2 \mathrm{a}$ & 4.4 & $5.4 \mathrm{ab}$ & 0.71 & $0.53 \mathrm{ab}$ \\
\hline & x PPSL-10 & 31.6 & $12.7 \mathrm{abc}$ & 19.1 & $8.4 \mathrm{a}$ & 2.9 & $1.8 \mathrm{ab}$ & 0.76 & $0.56 \mathrm{ab}$ \\
\hline & x 83-14-13 & 31.0 & 0.0 & 13.0 & 0.0 & 2.0 & 0.0 & 0.5 & 0.0--- \\
\hline & x 83-267-3 & 36.4 & $10.7 \mathrm{bc}$ & 21.3 & $6.1 \mathrm{a}$ & 2.0 & $1.2 \mathrm{a}$ & 0.83 & $0.36 \mathrm{~b}$ \\
\hline & x 85-341-9 & 32.2 & $10.3 \mathrm{abc}$ & 19.2 & $5.0 \mathrm{a}$ & 2.8 & $1.5 \mathrm{ab}$ & 0.77 & $0.39 \mathrm{~b}$ \\
\hline \multirow[t]{7}{*}{$83-14-13$} & Parent & 15.8 & 3.2 & 12.0 & 1.0 & 5.0 & 0.0 & 0.95 & 0.27 \\
\hline & Selfed & 26.0 & $0.0 \mathrm{ab}$ & 14.5 & $1.5 \mathrm{a}$ & 2.5 & $0.5 \mathrm{a}$ & 0.66 & $0.07 \mathrm{ab}$ \\
\hline & x aGSL-1 & 18.0 & $10.0 \mathrm{a}$ & 16.0 & $9.1 \mathrm{a}$ & 5.8 & $0.8 \mathrm{~b}$ & 1.74 & $0.96 \mathrm{ab}$ \\
\hline & x PPSL-10 & --- & --- & --- & --- & --- & --- & --- & --- \\
\hline & x 81-45-15 & 33.0 & 4.0 & 25.0 & 3.0 & 2.0 & $0.0-$ & 0.45 & 0.01 \\
\hline & x 83-267-3 & 18.5 & 4.4 & 16.5 & 2.2 & 2.0 & 0.7 & 1.31 & 0.38 \\
\hline & x 85-341-9 & --- & --- & --- & --- & --- & --- & --- & --- \\
\hline \multirow[t]{7}{*}{$83-267-3$} & Parent & 27.5 & 1.5 & 17.0 & 1.0 & 2.0 & 0.0 & 0.95 & 0.27 \\
\hline & Selfed & 29.2 & $11.3 \mathrm{abc}$ & 17.8 & $8.8 \mathrm{a}$ & 2.5 & $1.0 \mathrm{a}$ & 1.04 & $0.09 \mathrm{ab}$ \\
\hline & x aGSL-1 & --- & --- & --- & --- & --- & --- & --- & --- \\
\hline & x PPSL-10 & 35.0 & $10.6 \mathrm{abc}$ & 23.3 & $8.3 \mathrm{a}$ & 2.3 & $0.45 \mathrm{a}$ & 0.84 & $0.89 \mathrm{ab}$ \\
\hline & x 81-45-15 & --- & --- & --- & --- & --- & --- & --- & --- \\
\hline & x 83-14-13 & 32.8 & 0.2 & 16.0 & 1.0 & 3.0 & 0.0 & 1.7 & 1.12 \\
\hline & x 85-341-9 & 32.4 & $11.2 \mathrm{abc}$ & 18.7 & $6.6 \mathrm{a}$ & 2.7 & $1.4 \mathrm{a}$ & 0.63 & $0.15 \mathrm{~b}$ \\
\hline \multirow[t]{7}{*}{$85-341-9$} & Parent & 13.2 & 0.8 & 12.5 & 1.0 & 2.0 & 0.0 & 2.0 & 0.0 \\
\hline & Selfed & 27.8 & 4.2 & 15.0 & 2.0 & 3.5 & 0.5 & 0.39 & 0.11 \\
\hline & x aGSL-1 & --- & --- & --- & --- & --- & --- & --- & --- \\
\hline & x PPSL-10 & 45.1 & $6.6 \mathrm{c}$ & 25.0 & $4.2 \mathrm{a}$ & 4.7 & $2.4 \mathrm{ab}$ & 0.43 & $0.06 \mathrm{a}$ \\
\hline & x 81-45-15 & --- & --- & --- & --- & --- & --- & --- & --- \\
\hline & x 83-14-13 & --- & --- & --- & --- & --- & --- & --- & --- \\
\hline & x 83-267-3 & 29.6 & $13.6 \mathrm{abc}$ & 17.2 & $7.5 \mathrm{a}$ & 3.5 & $4.5 \mathrm{ab}$ & 0.71 & $0.45 \mathrm{ab}$ \\
\hline $\mathrm{MSE}^{\mathrm{w}}$ & & 122.2 & & 2.3 & & 4.0 & & 8.6 & \\
\hline
\end{tabular}

zMean separations within columns, based on 5\% Hochberg's. Parents and families with only one offspring were omitted from mean separation analysis.

yMean separations, based upon 5\% Games-Howell minimum significant differences (MSD). Parents and families with only one offspring were omitted from mean separation analysis.

${ }^{x}$ No progeny were available for analysis.

wEstimation of mean square error (MSE) used to calculate 5\% Hochberg's and MSD for mean separations. Means followed by different letters are significantly different from each other. 
One could select progeny that flowered as much as $25 \mathrm{~d}$ earlier than either parent (e.g., PPSL-10 x 83-14-13, Table 3). Likewise, significantly later flowering could also be found, e.g., $45 \mathrm{~d}$ for AGSL$1 \times 85-341-9$ progeny. SD $\times$ DN crosses fit a 1:3 ratio, indicating the $\mathrm{DN}$ is recessive to SD (Table 4), although DN $x$ DN crosses fit a 1: 3 ratio. HDI may be a confounding factor in this instance, however. Anderson and Ascher (1996) reported similar results for PSC that fit a 1:3 ratio (PSC:SI), but behaved as a quantitative trait.

Progeny LDLN ranged from 12 to 32 (Table 5), although none of the means differed significantly in the diallel due to the high levels of variation. Most progeny were within the LDLN range of 13 to 20 for the ideotype. LDLN narrow-sense heritability was $h^{2}=0.72$, similar to the broad-sense heritability $\left(h^{2}=0.79\right)$ of clones (Anderson and Ascher, 2001).

The significantly lowest leaf initiation rate was 0.43 leaves/d (85-341-9 x PPSL-10, Table 5) and the highest rates $(>1 / d)$ exceeded the ideotype (0.58-0.82; Anderson and Ascher, 2001) with either 83-267-3 or 83-14-13 inbreds as parents. While leaf initiation rates for garden types are not highly heritable $\left(h^{2}=0.003\right)$, in contrast with glasshouse germplasm $\left(h^{2}=0.767\right.$; Langton and Cockshull, 1976), progeny can be obtained within or greater than the ideotype.

Plant height (stem length) ranged from 18 to $45 \mathrm{~cm}$ for the diallel (Table 5), within the ideotype range (Anderson and Ascher, 2001). Within the exception of two crosses (83-14-13 x AGSL-1, 85-341-9 x PPSL-10), all progeny means overlapped and were not different (Table 5). Choice of parents is critical to achieving directional height changes; a breeder could select in either direction for height, depending on the desired phenotype. Plant height had a narrow-sense heritability of $h^{2}=0.66$, while earlier reports had a broad-sense heritability of $h^{2}=0.91$ (Anderson and Ascher, 2001).

The glasshouse photoperiod environment was established as the acid test for day neutrality in chrysanthemums (Anderson and Ascher, 2001). Use of a field environment in the present study was designed to test its rigor with the established glasshouse test environment. Based on the differing segregation results for DN:SD progeny, where more progeny flowered in the field than the glasshouse and $P$ values differed for $>1$ chi square test ratio in the DN $x$ DN crosses (Table 4), the field environment was not a discerning test environment. Clearly, Anderson and Ascher's (2001) glasshouse test environment remains the best test environment to determine true day neutrality in segregating chrysanthemum populations.

Since this is the first research using the ideotype for selection of DN/HDI progeny, it would not be expected that progeny would fit within the ideotype range for all traits. Early flower bud initiation (VBD) and development are the traits requiring significant improvement. None of the diallel progeny fell within the ideotype of 3 to 6 week response group. At least one or more progeny matched the ideotype for all other traits. While DN and HDI genotypes exist, further inbreeding, selection, and progeny testing is necessary before obtaining early flowering hybrids.

\section{Literature Cited}

Anderson, N.O. and P.D. Ascher. 1996. Inheritance of pseudo-self compatibility in self-incompatible garden and greenhouse chrysanthemums, Dendranthema grandiflora Tzvelv. Euphytica 87:153-164.
Anderson, N.O. and P.D. Ascher. 2001. Selection of day-neutral, heat delay insensitive Dendranthema $\times$ grandiflora genotypes. J.Amer. Soc. Hort. Sci. 126:710-721.

Anderson, N.O.; P.D. Ascher, and R.E. Widmer. 1988. Thin-layer chromatographic analysis of flower color phenotypes in Dendranthema grandiflora Ramatuelle inbreds and clonal cultivars. Euphytica 37: 229-239.

Anderson, N.O., P.D. Ascher, and R.E. Widmer. 1989. Chrysanthemum plant-day neutral. U.S. Plant Patent No. 6,884. (issued June 27, 1989) Wash., D.C.

Anderson, N.O., P.D. Ascher, and R.E. Widmer. 1992. Inbreeding depression in garden and glasshouse chrysanthemums: Germination and survivorship. Euphytica 62:155-169.

Anderson, N.O., P.D. Ascher, R.E. Widmer, and J.J. Luby. 1990. Rapid generation cycling of chrysanthemum using laboratory seed development and embryo rescue techniques. J. Amer. Soc. Hort. Sci. 115: 329-336.

Cockshull, K.E. and A.M. Kofranek. 1992. Responses of garden chrysanthemums to daylength. HortScience 27:113-115.

De Jong, J. 1978. Selection for wide temperature adaptation in Chrysanthemum morifolium. Neth. J. Agr. Sci. 26:110-118.

Fehr, W.R. 1987. Principles of cultivar development. vol. 1. MacMillan, New York.

Freeman, M.F. and J.W. Tukey. 1950. Transformations related to the angular and the square root. Ann. Math. Stat. 21:607-611.

Games, P.A. and J.F. Howell. 1976. Pairwise multiple comparison procedures with unequal $N$ 's and/or variances: A Monte Carlo study. J. Educ. Stat. 1:113-125.

Gravois, K.A. and R.W. McNew. 1993. Combining ability and heterosis in U.S. southern long-grain rice. Crop Sci. 33:83-86.

Griffing, B. 1956. Concept of general and specific combining ability in relation to diallel crossing systems. Austral. J. Biol. Sci. 9:463-493.

Hochberg, Y. 1970. Some generalizations of the T-method in simultaneous inference. J. Multivariate Anal. 4:224-234.

Hodgins, J.L. 1985. First record of an albino wild columbine, Aquilegia canadensis, for Ontario. Can. Field Nat. 99:385.

Kempthorne, O. and O.B. Tandon. 1953. The estimation of heritability by regression of offspring on parent. Biometrics 9:90-100.

Langton, F.A. 1977. The responses of early-flowering chrysanthemums to daylength. Scientia Hort. 1:277-289.

Langton, F.A. 1980. Chimerical structure and carotenoid inheritance in Chrysanthemum morifolium (Ramat.). Euphytica 29:807-812.

Langton, F.A. and K.E. Cockshull. 1976. An ideotype for chrysanthemum (C. morifolium Ramat.). Acta Hort. 63:165-175.

Liedl, B.E. and N.O. Anderson. 1986. SIGMAS-1: A software program for self-incompatibility genetic modeling. J. Hered. 77:480.

Liedl, B.E. and N.O. Anderson. 1993. Reproductive barriers: Identification, uses, and circumvention. Plant Breed. Rev. 11:11-154.

Mulford, F.L. 1937. Results of selfing twenty-four early blooming chrysanthemums. Proc. Amer. Soc. Hort. Sci. 35:818-821.

PanAmerican Seed Co. 2001. Product information guide. PanAmerican Seed Co., W. Chicago, Ill.

Ronald, W.G. 1974. Genetic and high temperature control of self compatibility in Chrysanthemum morifolium Ramat. PhD diss. Univ. Minn., St. Paul (Diss. Abstr. 35-3129).

Shimizu, A., M. Hirai, and H. Hirochika. 1998. Retrotransposon-like elements in Dendranthema pacificum (Nakai) Kitam. Acta Hort. 454:377-382.

Trevor Chandler, M., N. Tandeau de Marsac, and Y. DeKouchovsky. 1972. Photosynthetic growth of tobacco cells in liquid suspension. Can. J. Bot. 50:2265-2270.

United States NauticalAlmanac Office. 1977. Sunrise and sunset tables for key cities and weather stations of the U.S. Gale Res., Detroit, Mich.

Zhang, Y. and M. Kang. 1997. DIALLEL-SAS: A SAS program for Griffing's diallel analyses. Agron. J. 89:176-182. 